\title{
COMMUNITY KNOWLEDGE, ATTITUDES, AND BEHAVIOR TOWARDS SOCIAL DISTANCING POLICY AS A MEANS OF PREVENTING TRANSMISSION OF COVID-19 IN INDONESIA
}

\author{
Pengetahuan, Sikap, dan Perilaku Masyarakat terhadap Kebijakan Jaga Jarak sebagai \\ Cara Pencegahan Penularan COVID-19 di Indonesia
}

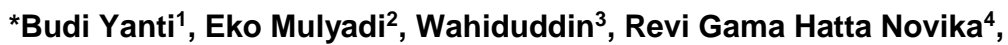 \\ Yuliana Mahdiyah Da'at Arina ${ }^{5}$, Natalia Sri Martani ${ }^{6}$, Nawan $^{6}$ \\ ${ }^{1}$ Department of Pulmonology and Medical Respirology, School of Medicine, Syiah Kuala University, Indonesia \\ ${ }^{2}$ Faculty of Health Sciences, Wiraraja University, Indonesia \\ ${ }^{3}$ Department of Epidemiology, Faculty of Public Health, Hasanuddin University, Indonesia \\ ${ }^{4}$ Master's Program in Public Health, Faculty of Medicine, Sebelas Maret University Surakarta \\ ${ }^{5}$ Department of Periodontology, Faculty of Dentistry, Jember University, Indonesia \\ ${ }^{6}$ Department of Microbiology, Faculty of Medicine, Palangkaraya University, Indonesia \\ ${ }^{*}$ Correspondence: byantipulmonologis@unsyiah.ac.id
}

\begin{abstract}
I

Background: Corona virus disease 2019 (COVID-19) caused by SARS-CoV-2 recently became a global pandemic, affecting countries, such as Indonesia, worldwide. Social distancing is one of the mitigation strategies recommended to reduce the risk of morbidity and mortality caused by COVID-19. Community compliance with social distancing is a part of the pandemic control.

Aims: This study identified knowledge, attitudes, and behavior towards the prevention of SARS-CoV-2 transmission through social distancing during the COVID-19 pandemic among the Indonesian community.

Methods: This descriptive study used a cross-sectional design, distributing closed questions in an online questionnaire randomly to 34 provinces in Indonesia on social media networks and by email. This study successfully collected data from 1,102 respondents from 29 provinces in Indonesia. The data were analyzed descriptively by calculating frequency, percentage, and cross-tabulation.

Results: This study successfully identified $99 \%, 59 \%$, and $93 \%$ of respondents with good knowledge, positive attitudes, and good behavior towards social distancing, respectively. Among the respondents who had good knowledge, $58.85 \%$ showed positive attitudes and $93.3 \%$ good behavior. The vast majority of respondents who had positive attitudes showed good behavior (96.7\%).

Conclusion: The Indonesian community had good knowledge, attitude, and behavior towards social distancing as a way to prevent the virus transmission. This strongly supports the use of such a disaster mitigation strategy in controlling the COVID-19 pandemic in Indonesia.
\end{abstract}

Keywords: attitudes, behavior, COVID-19, knowledge, social distancing.

\section{ABSTRAK}

Latar Belakang: Corona Virus Disease 2019 (COVID-19) yang disebabkan oleh SARS-CoV2 saat ini menyebar ke seluruh dunia, termasuk Indonesia. Social distancing merupakan salah satu mitigasi yang dianjurkan untuk mengurangi risiko bencana, seperti penyebaran dan kematian yang disebabkan oleh COVID-19. Kepatuhan masyarakat terhadap kebijakan social distancing adalah bagian untuk mengontrol pandemi ini.

Tujuan: Penelitian ini mengidentifikasi pengetahuan, sikap, dan perilaku terhadap pencegahan penyebaran SARSCoV-2 melalui kebijakan social distancing selama pandemi COVID-19 pada masyarakat Indonesia.

Metode: Penelitian deskriptif ini menggunakan desain cross-sectional secara acak menyebarkan pertanyaan tertutup di kuisioner online ke 34 provinsi di Indonesia melalui jejaring media sosial dan surat elektronik. Penelitian ini berhasil mengumpulkan 1,102 responden dari 29 provinsi di Indonesia. Data dianalisis secara deskriptif dengan menghitung frekuensi, persentase, dan tabulasi silang.

Hasil: Penelitian ini menunjukkan bahwa mayoritas responden memiliki pengetahuan yang baik (99\%), sikap positif (59\%), dan perilaku baik (93\%) terkait social distancing. Diantara responden yang memiliki pengetahuan yang baik juga menunjukkan sikap yang positif (58,85\%), dan perilaku yang baik (93,3\%). Responden yang memiliki sikap positif juga menunjukkan perilaku yang baik $(96,7 \%)$. 
Kesimpulan: Masyarakat Indonesia memiliki pengetahuan, dan perilaku baik juga sikap positif terhadap social distancing yang sangat berperan pada pengendalian penularan COVID-19. Hal ini sangat mendukung mitigasi bencana pandemi COVID-19 di Indonesia.

Kata kunci: sikap, perilaku, COVID-19, pengetahuan, social distancing.

Received: 21 April 2020

\section{INTRODUCTION}

The corona virus pandemic emerged when the virus was spread from person to person over a short period and in a sustained way. By December 2019, in terms of the clinical severity of pandemic disease, the corona virus disease 2019 (COVID-19) pandemic was rated from moderate to very high. The economic impact, an ignorant society, and the absence of targeted therapy and vaccination can affect the progress of a pandemic disease. Therefore a pandemic disease plan is needed as community mitigation to delay the disease peak, decrease stress on the health care system, protect critical infrastructure, and reduce the overall number of cases to decrease morbidity and mortality. Social distancing is one non-pharmaceutical intervention that can inhibit the virus spreading from infected case to susceptible case by arguing physical distance between people or decreasing congregation in the community in places, such as schools or workplaces (Ahmed, Zviedrite and Uzicanin, 2018).

COVID-19 was first reported in Wuhan, Hubei, China in December 2019, and on March 11, 2020 the World Health Organization (WHO) declared that COVID19 had become a pandemic disease worldwide (Bedford et al., 2020). Reported cases of COVID-19 were found in 203 countries around the world by the beginning of April 2020, with a total of 937,976 confirmed cases and 47,279 deaths. By April 2020, Indonesia showed a high number of confirmed cases and deaths in the COVID-19 outbreak, and a mitigation strategy was necessary to control the pandemic (American Library Association, 2020).

Coronavirus has previously caused two pandemics, namely the Severe Acute Respiratory Syndrome Coronavirus (SARS-CoV) in 2002-2003, in China, and the Middle East Respiratory Coronavirus Syndrome (MERS-CoV) in 2012-2013, in Saudi Arabia. The causative agents in both cases belonged to the coronavirus group, specifically the Betacoronavirus genus, which is transmitted through zoonosis. The current COVID-19 pandemic is the third pandemic caused by SARS-CoV-2, which is phylogenetically a part of the Betacoronavirus genus (Li et al., 2020; Prompetchara, Ketloy and Palaga, 2020). The main transmission route of SARSCoV-2 is through direct contact or consumption of the natural SARS-CoV-2 host, e.g., bats, and intermediate hosts, e.g., pangolins, snakes, and others (Hoffmann et al., 2020; Shereen et al., 2020). However, recent references indicated that bats, as natural hosts of SARS-CoV-2, are capable of infecting human cells without requiring an intermediate reservoir. The transmission of SARS-CoV-2 can occur from humans to other humans, especially among family members and friends who are in close contact with patients with COVID-19 or people infected with COVID-19 but without symptoms (Guo et al., 2020; Shereen et al., 2020) Research into a vaccine and drugs for SARS-CoV-2 is still underway; thus, a strategy is needed to prevent the process of transmission among humans. Social distancing is one of the community actions that can prevent disease transmission by reducing contact between people who can spread the virus (Maharaj and Kleczkowski, 
2012). Social distancing is one of the mitigation strategies recommended by the WHO for the world community during the SARS-CoV-2 pandemic (Guo et al., 2020). Social distancing is an essential part of pandemic control in reducing the possibility of the virus spread. Such a policy was once applied to an influenza pandemic in 2009. A simulation study of agent-based influenza showed that small changes in behavior can have a significant effect on transmission patterns during epidemics (Pawelek, Salmeron and Valle, 2015). Further research on agent-based models argued that social distancing can control epidemics if it starts quickly and continues for a long time (Kelso, Milne and Kelly, 2009).

The Indonesian government have also urged people to practice social distancing during the COVID-19 pandemic. Social distancing can reduce the mortality and morbidity of the disease, but the benefits of social distancing greatly depend on the understanding of individuals in the community (Reluga, 2010). The Indonesian government implemented policies related to social distancing, such as issuing commands to study and work from home, stay at home, and avoid contact, prohibiting activities in large numbers, and limiting operating hours in public places. Such social distancing is expected to reduce and control the spread of the coronavirus during this pandemic period. However, the big problem with this policy is that most of the Indonesian community have disobeyed this policy. The Indonesian community have still done other activities outside the home, been on vacation to various places, and returned to their home towns (Saifulloh, 2020). These phenomena might be caused by a lack of public knowledge and low concern about social distancing. Previously the Chinese government asked the public not to make a journey to Wuhan city, or elsewhere. The lockdown of Wuhan and several other cities in China has been seen

to effectively inhibit the high rate of transmission of COVID-19 cases to other provinces (Guan et al., 2020).

Therefore, this study aimed to identify the knowledge, attitudes, and behavior of the Indonesian community towards social distancing as a means of preventing COVID-19 transmission.

\section{METHODS}

This study was descriptive, using a cross sectional survey of the adult population in Indonesia. Data were collected through an indirect online questionnaire from March 10-20, 2020. These questionnaires, using closed questions and multiple-choice, were distributed to 34 provinces in Indonesia but only answered by 1,146 respondents in 29 provinces. The variables of this study were knowledge, attitudes, and behavior, and for each variable there were 10 items connected with using social distancing as one of the pandemic control strategies. Knowledge was measured by whether the respondents could identify the causes of the disease and transmission, general symptoms, risks and the prevention of COVID-19. Attitudes were measured according to the awareness of social distancing at work and worship, as well as learning from home. Behavior was related to carrying out prevention activities such as washing hands, avoiding touching the face, following cough and sneeze etiquette, wearing masks, and using disinfectant to prevent COVID-19.

The questionnaires consisted of three sections, concerning knowledge, attitudes, and behavior, each containing 10 related items, in addition to socio-demographic items such as province. The respondents provided information on age, educational level, occupation, and marital status. The questionnaires were purposed as a selfmanaged questionnaire, according to the standard protocols for questionnaire design 
and testing. The overall fields, concerns, and response options in the questionnaires were related to social distancing.

Knowledge and behavior measurement used the Guttman scale, and the Likert scale was used for attitude measurement. Data were analyzed with descriptive analysis by calculating the frequency, percentage, and crosstabulation.

\section{RESULTS AND DISCUSSION}

\section{Respondent Characteristics}

The study collected 1,146 questionnaires filled out online. After filtering, the data obtained from only 1,102 questionnaires could be processed.

Respondents came from 29 provinces out of 34 provinces in Indonesia. Most of them (40.47\%) were from East Java Province. One-third of the respondents were aged 26-45 years $(47.91 \%)$. Based on education level, $54.72 \%$ of the respondents were bachelor's, master's, and doctoral graduates. As many as $39.11 \%$ of the respondents were students/bachelor graduates/unemployed, and $36.84 \%$ worked as civil servants or for the Indonesian National Armed Forces. In terms of marital status, $50.09 \%$ of them were unmarried/single. The sociodemographic characteristics of the respondents are shown in Table 1.

Table 1. Respondents' Socio Demographic Characteristics

\begin{tabular}{lcc}
\hline \multicolumn{1}{c}{ Category } & $\begin{array}{c}\text { Frequency } \\
(\mathbf{n})\end{array}$ & $\begin{array}{c}\text { Percentage } \\
(\%)\end{array}$ \\
\hline Age Range & & \\
\hline 12-25 years old & 488 & $44.28 \%$ \\
$26-45$ years old & 528 & $47.91 \%$ \\
46-65 years old & 86 & $7.80 \%$ \\
Educational attainment & \\
Junior High & 25 & $2.27 \%$ \\
School & &
\end{tabular}

\begin{tabular}{|c|c|c|}
\hline Category & $\begin{array}{l}\text { Frequency } \\
\text { (n) }\end{array}$ & $\begin{array}{c}\text { Percentage } \\
(\%)\end{array}$ \\
\hline $\begin{array}{l}\text { Senior High } \\
\text { School }\end{array}$ & 394 & $35.75 \%$ \\
\hline $\begin{array}{l}\text { Associate } \\
\text { Degree }\end{array}$ & 80 & $7.26 \%$ \\
\hline $\begin{array}{l}\text { Bachelor, } \\
\text { Master and } \\
\text { Doctoral Degree }\end{array}$ & 603 & $54.72 \%$ \\
\hline Occupation & & \\
\hline $\begin{array}{l}\text { Civil } \\
\text { Servant/Indones } \\
\text { ian National } \\
\text { Armed Forces }\end{array}$ & 406 & $36.84 \%$ \\
\hline Housewives & 57 & $5.17 \%$ \\
\hline Entrepreneurs & 68 & $6.17 \%$ \\
\hline $\begin{array}{l}\text { Farmers/Fisher } \\
\text { men }\end{array}$ & 5 & $0.45 \%$ \\
\hline $\begin{array}{l}\text { Private } \\
\text { employees }\end{array}$ & 135 & $12.25 \%$ \\
\hline $\begin{array}{l}\text { Students/Colleg } \\
\text { e students / } \\
\text { Unemployed }\end{array}$ & 431 & $39.11 \%$ \\
\hline Marital Status & & \\
\hline Married & 529 & $48.00 \%$ \\
\hline Single & 552 & $50.09 \%$ \\
\hline $\begin{array}{l}\text { Divorced/Widow } \\
\text { ed /Widower }\end{array}$ & 21 & $1.91 \%$ \\
\hline
\end{tabular}

$\begin{array}{lcc}\text { Province } & & \\ \begin{array}{l}\text { Nangroe Aceh } \\ \text { Darussalam }\end{array} & 214 & 19.42 \% \\ \begin{array}{l}\text { North Sumatera } \\ \text { West Sumatera }\end{array} & 13 & 1.18 \% \\ \text { Riau } & 16 & 1.45 \% \\ \text { The Riau } & 2 & 0.18 \% \\ \text { Islands } & 5 & 0.45 \% \\ \text { South Sumatera } & 4 & 0.36 \% \\ \text { Bengkulu } & 1 & 0.09 \% \\ \text { Lampung } & 5 & 0.45 \% \\ \text { Banten } & 14 & 1.27 \% \\ \text { The Special } & 40 & 3.63 \% \\ \text { Capital Region } & & \\ \text { of Jakarta } & & \\ \text { West Java } & 35 & 3.18 \% \\ \text { Central Java } & 79 & 7.17 \% \\ \text { The Special } & 21 & 1.91 \% \\ \text { Region of } & & \\ \text { Yogyakarta } & & \end{array}$




\begin{tabular}{|c|c|c|}
\hline Category & $\begin{array}{l}\text { Frequency } \\
\text { (n) }\end{array}$ & $\begin{array}{c}\text { Percentage } \\
\text { (\%) }\end{array}$ \\
\hline East Java & 446 & $40.47 \%$ \\
\hline Bali & 8 & $0.73 \%$ \\
\hline $\begin{array}{l}\text { West Nusa } \\
\text { Tenggara }\end{array}$ & 4 & $0.36 \%$ \\
\hline $\begin{array}{l}\text { East Nusa } \\
\text { Tenggara }\end{array}$ & 1 & $0.09 \%$ \\
\hline $\begin{array}{l}\text { West } \\
\text { Kalimantan }\end{array}$ & 16 & $1.45 \%$ \\
\hline $\begin{array}{l}\text { Central } \\
\text { Kalimantan }\end{array}$ & 89 & $8.08 \%$ \\
\hline $\begin{array}{l}\text { South } \\
\text { Kalimantan }\end{array}$ & 5 & $0.45 \%$ \\
\hline $\begin{array}{l}\text { East } \\
\text { Kalimantan }\end{array}$ & 3 & $0.27 \%$ \\
\hline North Sulawesi & 2 & $0.18 \%$ \\
\hline West Sulawesi & 5 & $0.45 \%$ \\
\hline $\begin{array}{l}\text { Central } \\
\text { Sulawesi }\end{array}$ & 20 & $1.81 \%$ \\
\hline $\begin{array}{l}\text { Southwest } \\
\text { Sulawesi }\end{array}$ & 2 & $0.18 \%$ \\
\hline South Sulawesi & 45 & $4.08 \%$ \\
\hline Maluku & 2 & $0.18 \%$ \\
\hline North Maluku & 1 & $0.09 \%$ \\
\hline Papua & 4 & $0.36 \%$ \\
\hline Total & 1,102 & $100.00 \%$ \\
\hline
\end{tabular}

\begin{abstract}
This study used online questionnaires, so it only reached respondents who have access to technology and understand how to fill out questionnaires online. Although this presented a limitation to this study, online questionnaires are quick and convenient to use. In the future, another study could use hard-printed questionnaires to reach other respondents who cannot use technology.
\end{abstract}

\section{Respondents' Knowledge}

Knowledge is the consciousness of the human self-gained directly from life. An individual's knowledge comes from a process of learning attitude and behavior through teaching and training as influenced by the educational level of the individual or their community and includes the input of media that are designed to provide information to the public (Kast and Rosenzweig, 2003).

Health behavior is influenced by many factors, including knowledge, expectations of attitude change and behavior change. Knowledge is gained from an individual's own experience or that of others. Knowledge causes someone to obtain additional information through the use of common sense (Notoatmodjo, 2012). Individuals who have information will be able to determine how to react and make decisions when encountering a problem (Ahmadi, 2013).

The implementation of social distancing strategies should be recommended as a way of mitigating the COVID-19 pandemic all over the world. Epidemiological studies with various models have shown that social distancing can reduce the number of respiratory tract infection cases in diseases such as influenza. Droplets produced by coughing and sneezing are the primary sources of influenza transmission, thus social distancing can reduce the risk of person-toperson transmission that can occur at a distance of 3-6 feet (Ahmed et al., 2018).

This study showed that the majority of the respondents (99\%) had good knowledge of the use of social distancing to prevent COVID-19 transmission (Table 2). Since most of the respondents were either bachelor's, master's, or doctoral graduates, this is not surprising. However, this is one of the limitations of this study in that it only reached the community who understand technology. These findings are in accordance with what is stated in the Handbook of Health Economics. Many experts in the fields of economics, epidemiology, and public health have determined the relationship between health and education. This relationship does not depend on whether health is identified as health status or health behavior but it is clear that well-educated people are 
healthier and always engage in healthier behavior (Cowell, 2006).

Factors that influence the attainment of knowledge include educational level, the type of information, culture, and experience (Kapur, 2018; Sukanto, 2000). This study was conducted by online survey and the majority of respondents had completed higher education, so they were able to acquire any information about social distancing that was provided by the internet through social media more easily and quickly. All this may have influenced the level of knowledge found in this study.

Health literacy refers to managing individual behavior with regard to healthcare, disease prevention, and health promotion, with the health status of being sick, being at risk, and getting healthy. Health cognition is significant in enhancing the prevention and control of infectious diseases. Health knowledge and behavior are important components of health cognition. Health information can improve personal knowledge of infectious diseases and support the development of positive behaviors towards social distancing as a means of preventing and controlling infectious diseases. Health advancement relies on health information, which depends on health knowledge. Health information effectively includes information about infectious diseases. School health information programs not only provide students with knowledge and encourage appropriate behavior towards infectious diseases but also benefit the school community more widely. Therefore, health information education must strengthen the community's health cognition and improve personal knowledge, too (Wang et al., 2018).

An individual's knowledge of social distancing is expected to affect their attitudes and actions towards the social distancing policy to prevent the transmission of SARS-CoV-2 as the agent of COVID-19. This is consistent with the research conducted by Saunders-Hastings et al. (2016), which found that by enhancing knowledge of pandemic disease transmission, various interventions can strengthen the effectiveness of individual strategies to prevent a pandemic.

Table 2. Distribution of Indonesian Knowledge, Attitude, and Behavior Related to Social Distancing.

\begin{tabular}{lcc}
\hline Components & $\begin{array}{c}\text { Frequency } \\
\text { (n) }\end{array}$ & $\begin{array}{c}\text { Percentage } \\
\text { (\%) }\end{array}$ \\
\hline Knowledge & & \\
Good & 1,096 & $99 \%$ \\
Sufficient & 6 & $1 \%$ \\
Total & 1,102 & $100 \%$ \\
Attitude & & \\
Positive & 646 & $59 \%$ \\
Negative & 456 & $41 \%$ \\
Total & 1,102 & $100 \%$ \\
Behavior & & \\
Good & 1,029 & $93 \%$ \\
$\quad$ Sufficient & 73 & $7 \%$ \\
Total & 1,102 & $100 \%$ \\
\hline
\end{tabular}

\section{Respondents' Attitudes}

Human attitude is a predictor of normal behavior, although other factors such as environment and personal confidence may affect it. It means that attitude will determine actions, but sometimes attitude is not reflected in action. Consideration of whether something is good or bad will impact personal action. According to Anwar (1988), social attitudes are generated by social interaction. Through social interaction, individuals display a certain attitude towards a psychological object encountered. Various factors can influence attitudes, e.g., personal experiences, culture, information, educational institutions or religious institutions, as well as emotional factors within individuals. Attitude alteration occurs when data can be understood, accepted, and approved (Anwar, 1988).

This study showed that $59 \%$ of the respondents had positive attitudes towards 
social distancing as a non-pharmaceutical prevention of COVID-19 transmission in Indonesia (Table 2). The respondents' educational and occupational attainment, such as bachelor graduate or civil servant, influence their positive attitudes towards social distancing. Community attitudes towards COVID-19 prevention in this study support Sarwono's study (2007), which stated that attitude change could be achieved when individuals gain additional information about an object through persuasion and modification by the environment. Information in this context refers to that concerning what the importance of social distancing is. Anwar (1988) stated that knowledge has an important role in defining and enhancing an attitude. That is to say, knowledge will build up an attitude, as shown in Herman's study (Herman et al., 2015).

Social distancing is one of the pandemic strategies against COVID-19 urged by the World Health Organization and recognized by China and other countries during the COVID-19 pandemic. By providing a lot of information about infection and disease, it is expected that the community will become aware of and comply with all government regulations aimed at reducing the morbidity rate.

Attitude is a tendency that has not been accompanied by concrete actions towards behavior (Glass et al., 2006). Attitude is assumed to be an evaluative predisposition that significantly determines how individuals act, but the real attitudes and actions are often very different (Ajzen and Fishbein, 2000). The real action is determined not only by attitude, but also by various external factors (Glass et al., 2006).

This study showed that the majority of the respondents had a good attitude, meaning they were aware of the importance of social distancing. Attitude has three main components, i.e., awareness, feelings, and behavior (Robbins, 2007). Saying that "social

distancing is important" is an evaluative statement. This opinion is a cognitive component of attitude, which determines the level of attitude (affective component). Feelings are emotional segments (feelings of an attitude) reflected in statements, such as "I will do social distancing," and they can produce final behavior. The behavioral components of an attitude aim to change behavior so as to adjust to a particular condition (Robbins, 2007).

Attitudes are more likely to be stable and able to reflect behavior when the evaluative implications of the initial information are related to behavior. Two factors can influence the formation of an attitude. First, people can easily receive information (knowledge). Second, thinking about a problem can increase the tendency to form an attitude (Albarracín et al., 2001).This study is in line with the theory that most respondents have good knowledge about social distancing so they have good attitudes and behaviors in the discipline of doing social distancing.

\section{Respondents' Behaviors}

Behavior refers to personal action and reflection produced by the synchronization of the anatomical, physiological and psychological systems (Pawelek et al., 2015). There are three domains related to human behavior, namely the cognitive, affective, and conative domains. Elements of behavior consist of visible knowledge (cognitive) and attitude (affective), behaviors (psychomotor) and real action (action). The variety of behavior patterns and the process of its occurrence are important for all individuals, and can be influenced by pressure, motivation, and external support (Pawelek et al., 2015).

This study identified $93 \%$ of the respondents had good behavior towards social distancing for preventing the outbreak of COVID-19 in Indonesia (Table 2). Correspondence between information 
and initial attitude will guide how individuals behave in the future. Previous research revealed that attitudes would produce better behavior if attitudes and behavior correspond to target, context, time, and action. Other studies have also established that attitudes can produce good behavior when individuals rely on information that is relevant to the decision being made (Glass et al., 2006).

Health behavior is influenced by internal factors, including knowledge, perception, emotions, and motivation, and external factors (the physical and nonphysical environment). Cognitive knowledge is a very important domain for the formation of an individual's behavior. Knowledge of social distancing will underlie attitudes towards taking preventive actions and influence behavior (Darker et al., 2010). According to this study, the Indonesian community had good knowledge of social distancing as well as good attitudes and behaviors with respect to social distancing during the COVID-19 pandemic.

A previous study showed that many conventional aspects of human behavior depend on cultural norms so different cultures may respond with many alternative actions. The discovery of a new infectious disease may increase motivational pressures and change the level of behavior, depending on various factors such as the current information about a disease (knowledge) (Lewnard and Lo, 2020; Pawelek et al., 2015). There were 29 provinces participating in the present study, but despite having a diverse culture, the Indonesian community mostly showed good behavior towards social distancing.

Based on the Theory of Planned Behavior (TPB), intention is the best predictor of behavior (Barley and Lawson, 2016). Intention develops after an individual evaluates a change in behavior. This evaluation is influenced by attitudes, subjective norms and behavior control.
Society needs more than information to make behavioral changes. Public awareness of the importance of social distancing is influenced by various factors, including how much self-control people possess, which will be important for achieving a change in behavior (Barley and Lawson, 2016).

Health behavior depends on assumed intentions. Intention becomes a direct antecedent (the forerunner) of behavior (Ajzen, 2002). It depends on attitudes towards behavior, subjective norms, and perceived behavior control in accordance with the TPB. Banerjee (2020) proved that the intention of healthy Singaporean lifestyle behavior is positively related to attitudes, subjective norms, descriptive norms and behavioral control, in addition to the determinants of interpersonal communication and the mass media. Behavioral control based on the TPB originates from the Theory of SelfEfficacy proposed by Bandura, who derived it from Social Cognitive Theory (SCT). Reciprocal determinism is a central concept in SCT, which argues that behavior is the result of influences generated from within and outside, such as environmental factors (Bandura, 1986). This is in line with the results of this study that showed that the respondents who had good knowledge also had positive attitudes and good behavior.

In addition, powerful behavioral forces arise from the presence and behavior of other individuals. Behavior is influenced by individuals' perceptions of how other people think they should behave in a particular situation as well as of observation of how others behave. For example, it is reasonable to expect handshaking in some contexts because handshaking is a core expectation for social interaction and is perceived as normal on occasions such as a graduation ceremony. Moreover, given the novelty of the SARS-CoV-2 at this moment and the lack of reported cases, it is likely that most 
of the respondents were uncertain about the actual degree of risk faced, the importance of prevention behaviors, and the extent to which no handshaking would reduce risk. The optional handshaking instruction did nothing to reduce the ambiguity about the behavioral choice. When the appropriate behavioral response is ambiguous, and the objective guides to behavior are not available, individuals observe the behavior of others to infer the appropriate action. Thus, seeing handshaking during graduation ceremonies may have made people think that handshaking is the right action, thereby increasing pressure on mutual handshaking (Chaiklin, 2011).

The social forces in the situation combine to create a response conflict. Although the public health guidance to reduce disease transmission encourages individuals to avoid shaking hands, the social and situational demands of the graduation ceremonies encourage the opposite behavior, thereby rendering an optional handshake policy ineffective (Robinson et al., 2009).

The cross-tabulation between knowledge and attitude showed that of the respondents who had good knowledge, more than half $(58 \%)$ had a positive attitude. It means that the Indonesian community have good knowledge and a positive attitude. In terms of attitude and behavior, it indicated that almost all of the respondents who had a positive attitude $(96.7 \%)$ also had good behavior. This means that the Indonesian community has a positive attitude with good behavior. Furthermore, the results of cross-tabulation between knowledge and behavior indicated that nearly all of the respondents who had good knowledge (93.3\%) had good behavior. Overall, this study showed that the Indonesian community had good knowledge along with good behavior (Table 3).
Given that the role of knowledge showed a positive influence on behavior, this is also relevant to Bannet's Theory in Swan and Stepp (1979). This theory suggests that the behavior of those surrounding an individual will influence their behaviour, based on knowledge, attitudes and worth acceptance. Thus, behavior related to social distancing as a means of infectious disease prevention in the community always relies on knowledge of infectious disease prevention that has been broadcast through health information or health promotion. Furthermore, the results of this study, in accordance with Herman's study (2015), showed that knowledge of health and motivation to obtain information about the infectious disease could improve the prevention and control of the infectious disease (Herman et al., 2015).

The knowledge-attitude-behavior model modifies human health-related behaviors by dividing changes into three continuous processes, i.e., knowledge acquisition, belief generation and behavior formation (Liu et al., 2016). The knowledge-attitude-behavior model considers that knowledge is essential for effecting changes in behavior, and, thus, individuals can obtain knowledge and skills through learning (Liu et al., 2016).

This is the first study in Indonesia to identify knowledge, attitude and behavior towards social distancing. This study explained that a positive attitude results in good behavior. Attitude is an action of positive or negative tendency related to psychological objects. Real attitude shows the connotations of the suitability of reactions to certain stimuli, which in everyday life are emotional reactions. According to Thurston (1928), attitude as an action of a positive or negative tendency is associated with psychological objects. Actual attitudes show the connotation of the suitability of reactions to certain stimuli which in everyday life are emotional reactions to social stimuli. Attitude is the 
readiness to react to objects in a particular environment as a recognition of the objects.
Therefore, conducting social distancing requires the community's readiness.

Table 3. Cross-Tabulation between Knowledge, Attitude, and Behavior towards Social Distancing in Indonesia.

\begin{tabular}{|c|c|c|c|c|c|}
\hline \multirow{3}{*}{ Knowledge } & \multicolumn{4}{|c|}{ Attitude } & \multirow{3}{*}{ Total } \\
\hline & \multicolumn{2}{|c|}{ Negative } & \multicolumn{2}{|c|}{ Positive } & \\
\hline & $\mathbf{n}$ & $\%$ & $\mathbf{n}$ & $\%$ & \\
\hline Sufficient & 4 & 66.7 & 2 & 33.3 & 1,102 \\
\hline \multirow[t]{2}{*}{ Good } & 452 & 41.2 & 644 & 58.8 & \\
\hline & \multicolumn{4}{|c|}{ Behavior } & \\
\hline \multirow[t]{2}{*}{ Attitude } & \multicolumn{2}{|c|}{ Sufficient } & \multicolumn{2}{|c|}{ Good } & Total \\
\hline & $\mathbf{n}$ & $\%$ & $\mathbf{n}$ & $\%$ & \\
\hline Positive & 21 & 3.4 & 625 & 96.7 & 1,102 \\
\hline Negative & 52 & 11.4 & 404 & 88.6 & \\
\hline
\end{tabular}

\begin{tabular}{lccccc}
\hline \multirow{2}{*}{ Knowledge } & \multicolumn{4}{c}{ Behavior } & \multirow{2}{*}{ Total } \\
\cline { 2 - 5 } & \multicolumn{2}{c}{ Sufficient } & \multicolumn{2}{c}{ Good } & \\
\cline { 2 - 5 } & $\mathbf{n}$ & $\%$ & $\mathbf{n}$ & $\%$ & \\
\cline { 2 - 5 } Sufficient & 0 & 0 & 6 & 100 & 1,102 \\
Good & 73 & 6.7 & 1,023 & 93.3 & \\
\hline
\end{tabular}

Attitude is one of the variables that influence intention. Attitude towards behavior is one of the strong determinants of a weak intention to behave. A positive attitude towards behavior will increase the intention to behave and recognition of the behavior. Conversely, a negative attitude toward behavior will reduce the intention to behave and recognition of the behavior (Huda et al., 2012). This finding is consistent with the results of this study which showed that the Indonesian community had a positive attitude along with good behavior. Indeed, the influence of attitude on behavior is reinforced through intention. In addition to perceived behavior control, a positive attitude influences strong intention to perform social distancing in the community. A study by Jannuzzi et al.
(2020) showed attitude and subjective norms together explain $30 \%$ of the variability in intentions. Jannuzzi et al. defined attitude as a psychological construct, a mental and emotional entity that inheres in, or characterizes a person. It is an individual's predisposed state of mind regarding a value, precipitated through a responsive expression towards oneself. A subjective norm is the perceived social pressure to engage or not to engage in a behavior. It is necessary to include motivational strategies and targeted strategies to strengthen attitude and subjective norms in designing an intervention (Ferreira and Pereira, 2017).

\section{CONCLUSION}

This study concluded that, in general, the Indonesian community had good 
knowledge, positive attitudes, and good behavior towards social distancing to prevent the transmission of the COVID-19 pandemic in Indonesia. We suggest that these could inhibit the spread of COVID-19 in Indonesia, and, thus, the pandemic will be rapidly brought under control.

\section{CONFLICT OF INTEREST}

The authors state that there is no conflict of interest for this article.

\section{REFERENCES}

Ahmadi (2013) Kesehatan Masyarakat, teori dan aplikasi. Jakarta: Raja Grafindo.

Ahmed, F., Zviedrite, N. and Uzicanin, A. (2018) 'Effectiveness of workplace social distancing measures in reducing influenza transmission: $A$ systematic review', BMC Public Health. BMC Public Health, 18(518), pp. 1-13. doi: 10.1186/s12889-0185446-1.

Ajzen, I. (2002) 'Perceived Behavioral Control, Self-Efficacy, Locus of Control, and the Theory of Planned Behavior', Journal of Applied Social Psychology, 32(4), pp. 665-683. doi: $10.1111 / \mathrm{j} .1559-$ 1816.2002.tb00236.x.

Albarracin, D. et al. (2001) 'Theories of reasoned action and planned behavior as models of condom use: A meta-analysis.', Psychological bulletin, 127(1), pp. 142-161. doi: 10.1037/0033-2909.127.1.142.

American Library Association (2020) Covid-19 Corona Virus Pandemic, Worldometer. Available at: https://www.worldometers.info/coron avirus/?utm_campaign=homeAdveg as 1 ?\%22 (Accessed: 9 April 2020).

Anwar, S. (1988) Sikap Manusia dan Pegukurannya. Yogyakarta: Liberty. Bandura, C. E. (1986) Social foundations of thought and action. London: SAGE publication.

Barley, E. and Lawson, V. (2016) 'Using Health Psychology to Help Patients: Theories of Behaviour Change', British Journal of Nursing, 25(16), pp. 924-927.

Bedford, J. et al. (2020) 'COVID-19: towards controlling of a pandemic', The Lancet, 395(10229), pp. 10151018. doi: 10.1016/S01406736(20)30673-5.

Chaiklin, H. (2011) 'Attitudes, Behavior, and Social Practice', The Journal of Sociology \& Social Welfare, 38(1), pp. 31-54.

Cowell, A. J. (2006) 'The relationship between education and health behavior: Some empirical evidence', Health Economics, 15(2), pp. 125146. doi: 10.1002/hec.1019.

Darker, C. D. et al. (2010) 'An intervention to promote walking amongst the general population based on an "extended" theory of planned behaviour: a waiting list randomised controlled trial.', Psychology \& health, 25(1), pp. 71-88. doi: 10.1080/08870440902893716.

Ferreira, G. and Pereira, M. G. (2017) 'Physical activity: The importance of the extended theory of planned behavior, in type 2 Diabetes patients.', Journal of health psychology, 22(10), pp. 1312-1321. doi: $10.1177 / 1359105315626787$.

Glass, R. J. et al. (2006) 'Targeted social distancing design for pandemic influenza', Emerging Infectious Diseases, 12(11), pp. 1671-1681. doi: 10.3201/eid1211.060255.

Guan, W. J., Chen, R. C. and Zhong, N. S. (2020) 'Strategies for the prevention and management of coronavirus disease 2019', The European respiratory journal, 55(4). doi: 10.1183/13993003.00597-2020.

Guo, Y. R. et al. (2020) 'The origin, 
transmission and clinical therapies on coronavirus disease 2019 (COVID19) outbreak - an update on the status', Military Medical Research. Military Medical Research, 7(11), pp. 1-10. doi: 10.1186/s40779-02000240-0.

Herman, H. et al. (2015) 'The Community Disease Prevention Behaviors in District Maros South Sulawesi Province', International Education Studies, 8(11), pp. 104-112. doi: 10.5539/ies.v8n11p104.

Hoffmann, M. et al. (2020) 'SARS-CoV-2 Cell Entry Depends on ACE2 and TMPRSS2 and Is Blocked by a Clinically Proven Protease Inhibitor', Cell, 181(2), pp. 1-10. doi: 10.1016/j.cell.2020.02.052.

Huda, N. et al. (2012) 'The Analysis of Attitudes, Subjective Norms, and Behavioral Control on Muzakki's Intention to Pay Zakah', International Journal of Business and Social Science, 3(22), pp. 271-279.

Jannuzzi, F. F. et al. (2020) 'Psychosocial determinants of adherence to oral antidiabetic medication among people with type 2 diabetes.', Journal of clinical nursing, 29(5-6), pp. 909921. doi: 10.1111/jocn.15149.

Kapur, R. (2018) Impact of Culture on Education. Available at: https://www.researchgate.net/publica tion/323794724_Impact_of_Culture_ on_Education.

Kast, F. and Rosenzweig, J. (2003) Orgnasisi dan manajemen. 4th edn. Jakarta: Bumi Aksara.

Kelso, J. K., Milne, G. J. and Kelly, H. (2009) 'Simulation suggests that rapid activation of social distancing can arrest epidemic development due to a novel strain of influenza', $B M C$ Public Health, 9(117), pp. 1-10. doi: 10.1186/1471-2458-9-117.

Lewnard, J. A. and Lo, N. C. (2020) 'Scientific and ethical basis for social-

Community Knowledge, Attitudes...

distancing interventions against COVID-19', The Lancet Infectious Diseases. Elsevier Ltd, 3099(20), pp. 1-2. doi: 10.1016/s14733099(20)30190-0.

$\mathrm{Li}, \mathrm{X}$. et al. (2020) 'Molecular immune pathogenesis and diagnosis of COVID-19', Journal of Pharmaceutical Analysis. Elsevier Ltd, 10(2), pp. 102-108. doi: 10.1016/j.jpha.2020.03.001.

Liu, L. et al. (2016) 'Use of a knowledgeattitude-behaviour education programme for Chinese adults undergoing maintenance haemodialysis: Randomized controlled trial', The Journal of international medical research. 2016/03/07. SAGE Publications, 44(3), pp. 557-568. doi: 10.1177/0300060515604980.

Maharaj, S. and Kleczkowski, A. (2012) 'Controlling epidemic spread by social distancing: do it well or not at all.', BMC public health, 12(679), pp. 1-16. doi: 10.1186/1471-2458-12679.

Notoatmodjo, S. (2012) Promosi Kesehatan dan Perilaku Kesehatan. jakarta: Rineka Cipta.

Pawelek, K. A., Salmeron, C. and Valle, S. Del (2015) 'Connecting within and between-hosts dynamics in the influenza infection-staged epidemiological models with behavior change', Journal of Coupled Systems and Multiscale Dynamics, 3(3), pp. 233-243. doi: 10.1166/jcsmd.2015.1082.

Prompetchara, E., Ketloy, C. and Palaga, T. (2020) 'Immune responses in COVID-19 and potential vaccines: Lessons learned from SARS and MERS epidemic', Asian Pacific journal of allergy and immunology, 38(1), pp. 1-9. doi: 10.12932/AP200220-0772.

Reluga, T. C. (2010) 'Game theory of social 
distancing in response to an epidemic', PLoS Computational Biology, 6(5), pp. 1-9. doi: 10.1371/journal.pcbi.1000793.

Robbins, S. P. (2007) Perilaku Organisasi. Jakarta: Salemba Empat.

Robinson, J. G. et al. (2009) 'Attitudes About Health and Health-Related Behaviors in Patients With Cardiovascular Disease or at Elevated Risk for Cardiovascular Disease', Preventive Cardiology, 12(3), pp. 136-143. doi: 10.1111/j.1751-7141.2009.00037.x.

Saifulloh, M. (2020) Nafsu Mudik Dini ditengah Pandemic Corona. Available at: https://www.okezone.com/tren/read/ 2020/03/27/620/2190127/nafsumudik-dini-di-tengah-pandemi-viruscorona (Accessed: 23 April 2020).

Saunders-Hastings, P. R. and Krewski, D. (2016) 'Reviewing the history of pandemic influenza: Understanding patterns of emergence and transmission', Pathogens, 5(4), pp. $1-19$. doi: 10.3390/pathogens5040066.

Thurstone, L. L. (1928). 'Attitudes can be measured', American Journal of Sociology, 33, pp. 529-554. 